\title{
Penerapan Hidup Bersih dan Sehat (PHBS) untuk Penanganan Wabah Penyakit Demam Berdarah Dengue (DBD) di Dusun Besuk Desa Jabaran Kecamatan Balongbendo Sidoarjo
}

\author{
Yulianto Ade Prasetya, A’yunil Hisbiyah, Rizki Nur Hidayat, Merinsa Chorry Hartono, \\ Yesi Eka Nur Kumala Dewi \\ Program Studi DIII Analis Kesehatan, STIKES Rumah Sakit Anwar Medika Sidoarjo, \\ Jalan Raya By Pass Krian Km 33 Sidoarjo \\ Email Korespondensi: yuliantoadeprasetya@gmail.com
}

\begin{abstract}
Abstrak
Demam Berdarah merupakan penyakit tropis di negara berkembang termasuk Indonesia, yang masih perlu mendapat perhatian karena tingginya angka kematian. Dusun Besuk, Desa Jabaran, Kecamatan Balongbendo, Kabupaten Sidoarjo merupakan daerah yang sering terkena dasus Demam berdarah hingga berujung pada kematian. Sebanyak 58 warga kota Sidoarjo setiap bulan meninggal dunia karena penyakit tersebut. Rendahnya pengetahuan warga akan perilaku hidup bersih dan sehat menjadi salah satu penyebab tingginya angka kematian tersebut. Hal ini dibuktikan masih banyak warga yang membuang sampah di sungai Brantas, yakni sungai yang mengalir di daerah sekitar Dusun Besuk. Sedikitnya kader jumantik dan kurangnya pengelolaan sampah yang terpadu juga menjadi penyebab tingginya kasus DBD tersebut. Solusi yang ditawarkan yakni penyuluhan terhadap pengenalan penyakit demam berdarah termasuk pencegahannya yang termasuk dalam perilaku hidup bersih dan sehat (PHBS), penyuluhan dan pembuatan pupuk cair dari sampah organik, dan pembuatan tanaman hidroponik pengusir nyamuk, dan pembuatan taman amuk (anti nyamuk) untuk ditanami tanaman yang dapat mengusir nyamuk. Kegiatan tersebut dilaksanakan selama empat belas (14) hari. Hasil yang didapat meningkatnya pemahaman warga terhadap penyakit demam berdarah dan pencegahanya, warga mampu membuat tanaman hidropinik pengusir nyamuk dan mampu membuat pupuk cair dari sampah organik secara mandiri, serta terciptanya taman amuk (anti nyamuk) yang ditanami dengan tanaman sereh, jeruk, dan zordia.

Kata Kunci: Demam Berdarah, Dusun Besuk, Sidoarjo, perilaku hidup bersih
\end{abstract}

\section{PENDAHULUAN}

Demam Berdarah Dengue (DBD) merupakan penyakit yang disebabkan oleh virus Dengue yang ditularkan melalui nyamuk. Menurut WHO, lebih dari $40 \%$ penduduk dunia berisiko terhadap virus Dengue dan yang diperkirakan 50 juta per tahun terdapat infeksi baru (Regis, 2009). Kasus DBD setiap tahunnya dilaporkan sebanyak 925.896 di Dunia. Di Indonesia sendiri jumlah kasus DBD tercatat paling tinggi dibandingkan negara lain, termasuk di ASEAN. Data Kementerian Kesehatan Republik Indonesia (Kemenkes RI) mencatat jumlah kasus DBD pada tahun 2009 
mencapai sekitar 150.000. Demikian juga dengan tingkat kematiannya, tidak berubah dari 0,89\% pada tahun 2009 menjadi 0,87\% pada tahun 2010 (Pramudiarja, 2011). Desa Jabaran Kecamatan Balongbendo Kabupaten Sidoarjo Jawa Timur merupakan salah satu desa yang memiliki jumlah kasus DBD yang meningkat setiap tahunnya.

Desa Jabaran memiliki tiga dusun yakni Dusun Jabaran, Kapas Melati, dan Besuk dengan jumlah sepuluh Rukun Tetangga (RT) yang secara berurutan terdiri dari tujuh (7) RT, satu (1) RT, dan dua (2) RT. Dusun Besuk dengan jumlah dua RT yakni RT.01 dan RT.02 memiliki jumlah kasus Demam Berdarah Dengue (DBD) terbanyak, sehingga perlu mendapatkan perhatian. Dusun Besuk dilewati oleh sungai Brantas yang sudah beralih fungsi menjadi tempat pembuangan sampah sehingga banyak menimbulkan penyakit salah satunya DBD. Selain itu, warga desa Jabaran juga kurang sadar akan kebersihan lingkungan yang membuat nyamuk Aedes aegpyti sebagai perantara virus dengue semakin banyak berkembang biak dan menginfeksi manusia. Masyarakat dusun Besuk RT.01 RW.01 tingkat pendidikannya masih tergolong tinggi dan sangat kritis sedangkan masyarakat dusun Besuk RT.02 RW.01 tingkat pendidikannya tergolong kurang aktif. Pada dusun Besuk RT.02 memiliki permasalahan tentang kondisi saluran selokan di lingkungan sekitar masih terhambat atau belum lancar. Keadaan lingkungan sekitar dusun Besuk RT.01 dan RT.02 RW.01 sudah mulai bersih dari persoalan sampah, karena sudah ada tempat sampah di sepanjang jalan dan kemudian ada petugas kebersihan yang menggangkut sampah dari dusun Besuk RT.01 dan RT.02 ke TPU desa Jabaran yang terletak di dusun Jabaran RT.10, Namun masih ada beberapa warga yang pembuangan sampahnya melakukan dengan membakar sampah tersebut. Dusun Besuk sudah memiliki kader Jumantik sebanyak dua orang, namun angka morbititas dan mortalitas masih tinggi di daerah tersebut. Sosialisasi pencegahan DBD seperti 3M (menguras, menutup, dan mengubur) dan pemberian Abate masih belum efektif. Hal ini disebabkan karena jumlah kader jumantik tidak sebanding dengan jumlah Kartu Keluarga (KK) di Dusun Besuk RT.01 dan RT.02. Selain itu, rendahnya angka kesadaran warga terhadap bahaya DBD dan kebersihan lingkungan seperti Sungai juga menjadi salah satu penyebab tingginya kasus DBD. Pencegahan dan penyebaran penyakit DBD dapat diatasi dengan lebih meningkatkan program yang telah berjalan dan program baru yang dibuat dalam menanggulangi penyakit DBD di Dusun Besuk, Desa Jabaran, Kabupaten Sidoarjo Jawa Timur.

\section{METODE}

Berdasarkan analisis situasi dan permasalah mitra dari uraian di atas, maka diperlukan beberapa solusi sebagai berikut:

a) Sosialisasi bahaya Demam Berdarah Dengue (DBD) di Desa Besuk yang dilakukan secara berkala di tiap RT.

b) Pelaksanaan program pembuatan pupuk cair dan pupuk cair dari sampah organik yang terdiri dari sosialisasi dan pelatihan.

c) Pembuatan taman mini yang berguna untuk masyarakat dusun Besuk RT.01 dan RT.02 RW.01 Jabaran. 
Yulianto Ade Prasetya, dkk.

Program pembangunan Kesehatan Masyarakat Desa (PKMD) memiliki target luaran yang dapat dilihat melalui berbagai aspek sebagai berikut:

a) Leaflet sebagai sosialisasi untuk warga yang terdiri dari Bahaya Demam Berdarah Dengue (DBD) termasuk pencegahannya

b) Banner sebagai media informasi pada warga bahwa acara PKMD berjalan.

c) Poster pembuatan Pupuk dari sampah organic (Pupuk Cair dan Pupuk Bokashi) dan Cara penanaman metode Hidroponik

d) Laporan Pembangunan Kesehatan Masyarakat Desa (PKMD).

e) Pengelolaan pupuk organik dari sampah organic yang kreatif

f) Mading taman sebagai media informasi

Metode pelaksanaan pada program Pembangunan Kesehatan Masyarakat Desa yang berjudul Penerapan Konsep Lingkungan Bersih dan Sehat Bebas dari Demam Berdarah Dengue (DBD) di Dusun Besuk Desa Jabaran Kecamatan Balongbendo Kabupaten Sidoarjo ini yakni sebagai berikut:

a) Survei Awal: Kegiatan Pembangunan Kesehatan Masyarakat Desa dimulai dari pemberian surat izin kepada Kepala Desa Jabaran untuk mengadakan kegiatan. Pencarian informasi tentang masalah kesehatan yang dialami warga kepada Kepala Desa, Ketua RT, Bidan Desa, dan Kader lingkungan di Desa Jabaran

b) Identifikasi Masalah: Hasil survey yang sudah dilakukan kemudian dilanjutkan dengan identifikasi masalah yang sering dialami warga Desa Jabaran. Masalah kesehatan yang masih belum terselesaikan di desa Jabaran yakni Demam Berdarah Dengue (DBD) tepatnya di dusun Besuk RT.01 dan RT.02 yang angka kejadiannya masih tinggi pada tahun 2016. Masalah yang sudah terindetifikasi kemudian dicari akan permasalahannya untuk dicarikan solusi.

c) Analisis Kebutuhan: Analisis kebutuhan dibuat dari hasil identifikasi masalah yang sudah dilakukan dan telah dirumuskan solusi berupa program yang akan dilakukan.

d) Penetapan Sasaran: Sasaran harus tepat dan dibuat sesuai dengan program kerja yang direncanakan agar indikator pencapaian program dapat terwujud.

e) Penyusunan Program: Gagasan program yang dibuat sesuai dengan analisis kebutuhan dan penetapan sasaran yakni berupa sosialisasi bahaya DBD dan pencegahannya, sosialisasi kebersihan lingkungan, pembuatan pupuk bokasi dan pupuk cair, sosialisasi cara penanaman hidroponik pembuatan taman AMUK (Anti nyamuk).

f) Pelaksanaan Program: Pembangunan kesehatan masyarakat desa dilaksanakan mulai tanggal 2-13 April 2018.

g) Monitor dan evaluasi keberhasilan: Evaluasi ini bertujuan untuk melihat perkembangan program yang dilaksanakan, untuk mengetahui kendala yang ada, cara menanganinya sehingga program Pembangunan Kesehatan Masyarakat Desa yang dilakukan benar-benar efektif dan maksimal. Evaluasi yang terakhir yaitu berupa laporan kegiatan Pembangunan Kesehatan Masyarakat Desa 


\section{HASIL DAN PEMBAHASAN}

Berdasarkan hasil pendataan dan survei yang dilakukan di desa Jabaran, Kecamatan Balongbendo didapatkan bahwa keadaan geografis di Dusun Besuk adalah :

- Utara : Jalan Raya By Pass

- Selatan : Sungai

- Timur : Desa Semawut

- Barat : Dusun Kapas Mlati, Desa Jabaran

Keadaan demografi dari hasil pendataan pada warga Dusun Besuk (RT 1 dan RT 2) jumlah keseluruhan kepala keluarga di Dusun Besuk ialah sebanyak 195 Kepala Keluarga yang terdiri atas 160 rumah. Data sasaran yang diambil untuk dilakukan PKMD di Dusun Besuk antara lain : Usaha pencegahan Demam Berdarah dari warga Dusun Besuk yang belum pernah dilakukan.

Data sampel yang diambil ialah sebanyak hasil pendataan yakni 195 Kepala Keluarga, berdasarkan data tersebut dijadikan sampel untuk dilakukan penyuiluhan, sosialisasi dan pelatihan pembuatan pupuk dan penanaman metode hidroponik.

Berdasarkan penyuluhan yang dilakukan masyarakat dapat menanggapi dengan positif terbukti dari jumlah undangan sebanyak 50 undangan yang terdiri dati RT 1 dan RT 2, peserta penyuluhan yang hadir sebanyak 20 orang. Peserta mengerti tentang penyuluhan yang telah diberikan dan mampu untuk mengulang penjelasan yang telah diberikan, serta tanggap dalam mengikuti penyuluhan. Penyuluhan DBD dilakukan untuk memberikan informasi pada warga tentang penyakit yang disebabkan oleh DBD.
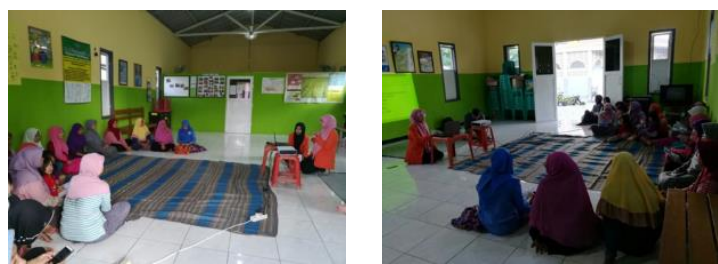

Gambar 1. Penyuluhan Demam Berdarah dan Pencegahannya di Dusun Besuk Desa Jabaran Kecamatan Balongbendo Kabupaten Sidoarjo

Berdasarkan sosialisasi pembuatan pupuk cair dari nasi basi, warga menanggapi hal tersebut dengan positif dan memberikan apresiasi yang antusias. Hal tersebut nampak saat salah satu anggota kami memberikan contoh pembuatan, warga ikut menirukan. Sosialisasi pembuatan pupuk cair ini dilakukan tujuannya ialah untuk mengurangi pembuangan limbah rumah tangga, selain itu sebagai nutrisi tanaman pengusir nyamuk dengan metode hidroponik. 
Yulianto Ade Prasetya, dkk.
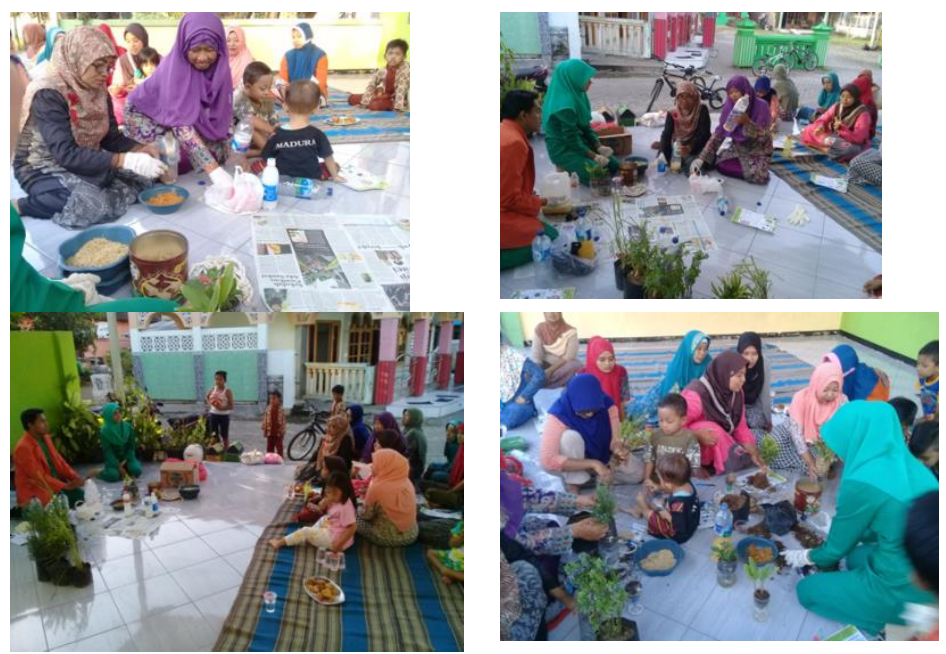

Gambar 2. Pembuatan pupuk cair bokashi

Berdasarkan penanaman tanaman anti metode Hidroponik, warga menanggapi hal tersebut dengan positif dan memberikan apresiasi yang antusias. Hal tersebut nampak saat salah satu anggota kami memberikan contoh pembuatan, warga antusias ikut menanam. Tujuan pelatihan penanaman tanaman pengusir nyamuk metode Hidroponik ialah sebagai metode lain menanam tanpa menyiram serta tanaman dapat diletakkan didalam rumah terutama dibagian sudut - sudut kamar sebagai tindakan preventif untuk mengurangi populasi nyamuk didalam rumah.
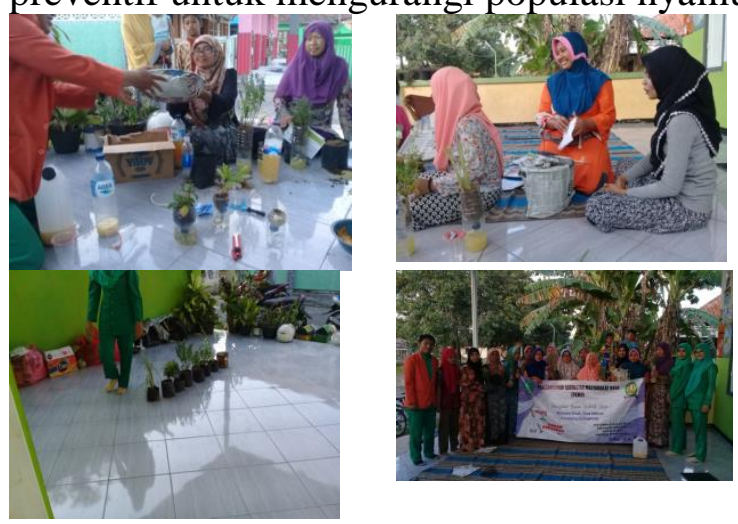

Gambar 3. Pembuatan tanaman hidroponik

Berdasarkan pembuatan taman yang telah dilakukan yang berlokasi didekat PONKESDES, warga sangat senang. Hal itu nampak saat pembuatan taman selama 5 hari berturut - turut ada beberapa warga yang lalu lalang melewati depan taman, warga memberikan tanggapan yang positif dan sangat mendukung pembuatan taman. Pembuatan taman tidak sekedar hanya untuk memperindah lingkungan dusun besuk, lebih dari itu harapan kita dengan adanya taman tersebut dapat dirawat dan dimanfaatkan oleh warga sebagai sarana edukasi tentang macam - macam tanaman pengusir nyamuk. Selain itu, penanaman tanaman pengusir nyamuk pada taman bertujuan agar dapat dibudidayakan dengan cara distek di rumah - rumah warga, sebab 
dengan jumlah rumah 80 rumah per RT, dana yang yang diberikan tidaklah cukup sehingga adanya sebidang tanah hibah dipergunakan sebagai taman dan harapan kami agar wabah DBD di dusun Besuk semakin berkurang serta lingkungan semakin bersih.
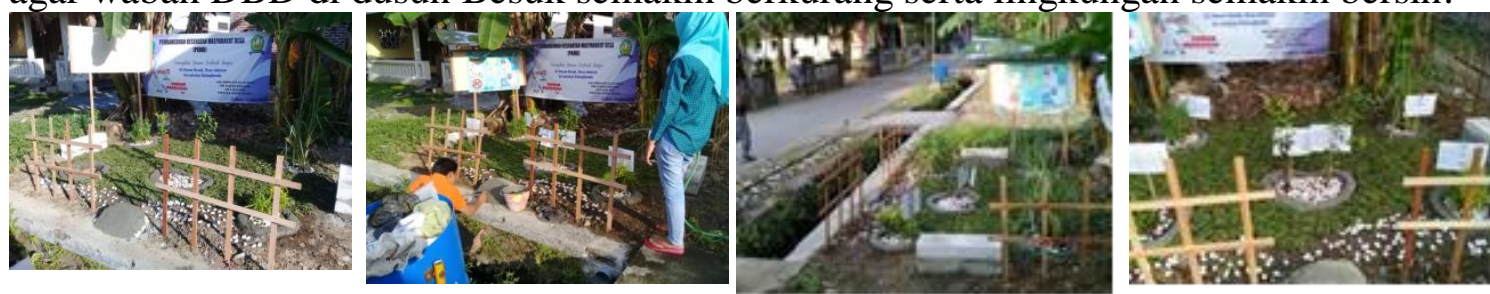

Gambar 4 Pembuatan taman Amuk (Anti Nyamuk)

\section{PENUTUP}

\section{Simpulan}

Upaya terhadap pencegahan demam berdarah sangat penting terutama untuk daerah seperti Dusun Besuk, Desa Jabaran, Kecamatan Balongbendo, Kabupaten Sidoarjo yang memiliki riwayat dimana warganya sering meninggal akibat demam berdarah. Selain pemberian abate dan $3 \mathrm{M}$ plus yang sudah dicanangkan pemerintah namun hasilnya belumlah optimal. Dengan adanya pengabdian kepada masyarakat berupa perilaku hidup bersih dan sehat (PHBS) seperti penyuluhan demam berdarah dan pencegahannya, pembuatan pupuk cair bokahshi dari sampah organik, dan pembuatan tanaman hidroponik dan taman amuk (anti nyamuk) dapat membantu warga untuk mencegah tejadinya penyebaran penyakit demam berdarah.

\section{Saran}

Saran pada kegiatan ini yakni diperlukan adanya kegiatan monitoring secara berkelanjutan terhadap program yang sudah dilaksanakan seperti penyiraman taman amuk yang sudah dibuat dan pengecegakan terhadap seberapa efektinya tanaman hidroponik dalam mengusir nyamuk serta efektinya pembuatan pupuk cair untuk mengurangi sampah organik warga.

\section{DAFTAR PUSTAKA}

Thavara (2006). Double Infection of Heteroserotypes of Dengue Viruses in Field Populations of Aedes aegypti and Aedes albopictus (Diptera: Culicidae) and Serological Features of Dengue Viruses Found in Patients in Southern Thailand. Southeast Asian J Trop Med Public Health. 37: 468 - 76.

Regis L (2009). An Entomological Surveillance System Based on Open Spatial Information for Participative Dengue Control. Annals of the Brazilian Academy of Sciences. 81(4): 655 - 662.

Depkes RI (2007). Modul Pelatihan Bagi Pengelola Program Pengendalian Penyakit DBD di Indonesia.

Dinkes Provinsi Jateng (2009). Laporan Kasus DBD Jawa Tengah sampai November 2009 